



\title{
A METHOD OF TRANSPORTING LIVE FISHES
}

\author{
By Charles F. Holder
}

Paper presented before the Fourth International Fishery Congress held at Washington, U. S. A., September 22 to 26, 1908

BULLETIN OF THE BUREAU OF FISHERIES : : : $:$ : : VOL. XXVIII, P. 1005-1007

Document No. 702 : : : : : : : : : : : : : : : : : : : : : Issued April, 1910 


$$
\text { कम } x^{5}
$$

APR 151910

B o

$$
\therefore \vdots
$$




\title{
A METHOD OF TRANSPORTING LIVE FISHES.
}

\author{
BY CHARLES F. HOLDER.
}

*

In my somewhat extended experience in handling and transporting live fishes the following has proved the most satisfactory method, as illustrated on a particular occasion:

Large numbers of fish of different kinds were to be collected, upon contract, from fishermen along the Hudson River, from the mouth as far up as Fishkill. My boat, chartered for the purpose, was a water boat, or large tug, with her tanks filled with fresh water and her decks covered with galvanized-iron tanks for salt water. The fishermen came alongside with their fish in live cars, or the tug steamed up to the big nets; cans were sunk beside the cars or the nets, and the fish were transferred without being touched by hand.

A few hours later the tug landed in New York, where big drays, loaded with cans, were in readiness. The insides of the cans were covered with sponges wired into wire fencing and pressed against the interior of the can, the sponges swelling when wet and forming a perfectly soft pad for the fishes. These cans were lowered by a derrick into the tanks of the tug, where men standing in the water transferred the fish to them by means of very wide fine-mesh nets, never touching the fish with their hands. As each can was filled, which was done with great rapidity, it was hoisted to the deck and covered with a tin cap which had an inner false bottom perforated with small holes. With this, at the slightest tip from the horizontal, water flowed into the perforations and dropped back in a shower, thus aerating itself. The moment a dray was loaded it was driven away, not carefully but at a run or fast trot, to the aquarium, the rapid motion being less dangerous to the fish than a long swing.

The original and distinctive features of this method of transporting live fishes are the sponge-lined tanks and the self-aerating device. The latter can not be exclusively depended upon-I found it necessary to make the round of the tanks with a large syringe-but the false lining of the tops reduced the hand labor 50 per cent; and on shipboard, for instance, when the motion is sufficient, it is my belief that fishes might live a week with this automatic aeration of the water in the cans.

I used this method of transporting fishes first in 1876 , and on numerous occasions since have found it successful. A chief feature is the care in handling, not a fish being touched by hand, and thus, with the cushioned tanks, not a fish being injured. The sponges also prevent the loss of water. 
LIBRARY OF CONGRESS

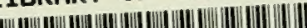

00028625741 